\title{
Analysis of Student Mathematical Anxiety Based on Gender and Educational Infrastructure
}

\author{
Nasruliyah Hikmatul Maghfiroh ${ }^{\mathrm{a} *}$, Fattah Hanurawan $^{\mathrm{b}}$, Imanuel Hitipeuw $^{\mathrm{c}}$, Endang Prastuti $^{\mathrm{d}}$ \\ a, b, c, d Faculty of Educational Psychology, Universitas Negeri Malang, Indonesia \\ a*Email: nasruliyahhikmatulmaghfiroh85@gmail.com
}

Article History: Received: 10 November 2020; Revised 12 January 2021 Accepted: 27 January 2021; Published online: 5 April 2021

\begin{abstract}
Anxiety is a problem that arises from the gap between expectations and reality. Many factors influence mathematical anxiety (MA), one of which is the availability of educational infrastructure. Although MA has been widely researched, only a few studies have explored how gender and the availability of educational infrastructure form the basis for analyzing MA. By knowing student MA, it will help teachers to provide alternative educational foundation based on their gender analysis. This research aims to examine student MA based on gender and the availability of educational infrastructure. This research involved 450 senior high school students in East Java, Indonesia. The data were processed using univariate analysis. The results of the study reveal that gender does not significantly influence student MA, while educational infrastructure significantly influences students MA. There is no interaction between gender and educational infrastructure on student MA. It is implied that, by understanding the student MA, it allows teachers to guide students who have an MA based on their area of origin according to the level of availability of educational infrastructure.
\end{abstract}

Keywords: Mathematical Anxiety, Gender, access to education

\section{Introduction}

Learning is a permanent influence on behavior, knowledge, and thinking skills acquired through experience (Santrock, 2018; Slavin, 2006). A student learns when there has been a change in his/her behavior even though it is not always acquired from learning activities (Santrock, 2018). Student learning experiences with one another are very diverse, usually related to the speed of the learning process (e.g., results obtained) or feelings after learning (e.g., joy, motivation, sadness, fear, and anxiety).

Positive learning outcomes are followed by positive feelings while negative learning outcomes are followed by negative feelings. This has become a common phenomenon for elementary to college students (Akbayır, 2019; Peker \& Şentürk, 2012). Students are more likely to repeat fun activities regardless of not optimal results; on the other hand, scary and worrisome events tend to be abandoned(Schunk \& DiBenedetto, 2020), such as anxiety about mathematics (Akbayır, 2019).

Anxiety is a feeling obtained by students through theory-oriented learning conditioning. This situation sometimes encourages students to behave creatively and constructively, but, in some other cases, prevents such behavior (Akbayır, 2019; Dursun \& Bindak, 2011). Anxiety is closely related to restlessness, fear, and contemplation caused by conditions around the students (Akbayır, 2019; Namkung et al., 2019).

Students' feelings of mathematics anxiety have been studied for a long time, as did Richardson and Suinn (1972) showing that mathematics learning is learning that causes tension because its tasks are related to the use of numbers in everyday life such as counting money, checking credits and debits of bank accounts, evaluating sales prices, and sharing the workload among students (Akbayır, 2019; Richardson \& Suinn, 1972).

Other researchers A. M. Olson \& Stoehr (2019) suggest that mathematical anxiety (MA) is described as a stress response that is supported by adverse physiological reactions (such as nausea, fast heartbeat, and cold sweat) when engaging or thinking about math tasks. As a result, students are afraid of taking math subjects and even hate math (Akbayır, 2019; Alkan, 2011; Aydin \& Keskin, 2017).

Recently, there have been many studies on MA as a phenomenon associated with gender, but only a few have linked it to the availability of educational infrastructure in a region. Each area where students live has various availability of access and infrastructure that support learning and education. This diversity depends on the geographic location and financial capacity of each region in providing educational facilities and infrastructure. Understanding gender characteristics and educational foundation for students can help teachers reduce and solve problems related to student MA. 
Research on MA and gender shows a negative reciprocal relationship between MA and self-perception in male students instead of females. Male students have higher MA than females (Wang et al., 2020). However, when it comes to intellectual abilities, both are the same. The difference is only in cognitive areas such as verbal skills (Halpern, 2012). The latest research results related to the level of availability of access to education Adetunji \& Aloba (2018) emphasize that schools should provide the various needs of students for maximum results; besides, quality assurance must be prioritized.

As the results of previous research are limited, further research is needed to clarify the relationship between gender, educational infrastructure, and student MA. We hope this research can contribute to explaining the results of recent study in the future.

Based on previous research, we hypothesize that (1) gender difference affects student MA and (2) differences in educational infrastructure affect student MA. In this article, we researched to analyze whether gender difference and educational infrastructure influence student MA.

\section{Literature Review}

\section{Gender Characteristics}

According to Santrock (2018), the goal of the discussion on gender lies in the socio-cultural and psychological dimensions differentiated by gender, both men and women. By understanding the meaning of gender, men and women will think, feel, and act as they should. Many have researched and debated the thinking and learning abilities of men and women, but, until now, no researcher has been responsible for conveying that men and women have different intellectual skills (Slavin, 2006). Anatomically, the male and female brain is similar, and it does not determine differences in behavior and attitudes from gender (Santrock, 2018).

Despite the biological difference, men and women will look very different in terms of physical abilities due to hormones in which men gain muscle mass while women gain fat with age (Lindsey, 2016; Santrock, 2018). This condition causes men to be more active, making men superior to women in physical education (Eisenberg et al., 1996; Santrock, 2018). Due to this activeness, men have a higher risk factor than women in dropping out of school (DeZolt \& Hull, 2001; Koch, 2003).

Men tend to have better math and science skills than women (DeZolt \& Hull, 2001; Koch, 2003; Santrock, 2018). Although most male students have an excellent achievement, $50 \%$ of the students with lousy performance are male (DeZolt \& Hull, 2001). Women have better verbal skills, such as writing and reading, than men (DeZolt \& Hull, 2001; Halpern, 2012; Lindsey, 2016). The results of this research cannot be generalized because it is related to the socio-cultural environment and student learning facilities (Santrock, 2018; Slavin, 2006).

\section{Educational Infrastructure (EI)}

There are various discussions about educational infrastructures, such as infrastructure based on demographic location, school systems, learning tools, school buildings, technology strengthening, etc. (Takmazyan et al., 2019). Also, the discussion of educational infrastructure is related to educational organizations and scholarships (Skobeltsina \& Kuznetsov, 2019).

The school system's educational infrastructure, such as structured routines and instructional training, can influence the frequency of teacher interactions with their colleagues in the workplace as well as the quality of the interactions (Shirrell et al., 2019). For example, a lesson study in Japan provides structured opportunities for teachers to interact with and explore mathematics (Stigler \& Hiebert, 1999).The Chinese school system allows teachers to plan and reflect on mathematics learning (Ma, 2010); learning communities can support meaningful and instructively focused interactions among teachers (J. P. Spillane et al., 2016). Other school system infrastructure shows that focusing educational foundation based on the general purpose of mathematics can help facilitate changes in teacher beliefs (Hopkins et al., 2017; Hopkins \& Spillane, 2015; Sun et al., 2014).

EI in this research emphasizes the availability of educational infrastructure based on the demographic location of a region. Based on this, there are three levels of EI, namely level 1 (lowest level, where educational infrastructure is still minimal and only reach a few people).Level 2 (intermediate level, where educational support is considered sufficient to reach several groups of people) and level 3 (highest level, where educational infrastructure is widely available and accessible to the community).

\section{Mathematical Anxiety (MA)}

Many researchers link MA with mathematical performance (Namkung et al., 2019; Wang et al., 2020; Zakaria et al., 2012).Some research links it with gender (Akbayır, 2019; Aydin \& Keskin, 2017; Goetz et al., 2013) while others think that MA is a significant risk factor that hinders the development of student self-confidence and abilities in mathematics, science, technology, engineering, and math-related work (Wang et al., 2020). If MA is 
not taken seriously, it will result in students hating mathematics and eventually dropping out of school (Carey et al., 2019; Carvalho, 2016; Gresham \& Burleigh, 2019; Olson \& Stoehr, 2019).

MA first appears in young children around six years of age (Beilock et al., 2010; Carey et al., 2019; Vukovic et al., 2013). However, there is an adverse reaction to MA for middle-school-age children (Carey et al., 2019; Dowker et al., 2016). To determine whether a child has MA or not is very difficult because the indicators for each individual are different (Akbayır, 2019; Carey et al., 2019; Devine et al., 2016).

MA is a feeling of discomfort such as tension or worry that interferes with math performance both in daily life and learning at school (Carey et al., 2019; Delgado \& Kassim, 2019; Namkung et al., 2019; Vukovic et al., 2013). This feeling causes students to avoid and refuse to study mathematics and even hate it (Carey et al., 2019; Carvalho, 2016; Gresham \& Burleigh, 2019; Olson \& Stoehr, 2019). Studying mathematics is considered necessary because students learn about numbers to solve calculations from simple to complex in everyday life (Akbayır, 2019; Carey et al., 2019; Olson \& Stoehr, 2019; Wang et al., 2020).

Several possible causes of MA have been identified, i.e. negative classroom experience due to student's low basic math skills (Carey et al., 2019; Gresham \& Burleigh, 2019; Maloney et al., 2011); teacher characteristics, e.g. women tend to have MA if the teacher is female (Beilock et al., 2010; Delgado \& Kassim, 2019; Maloney et al., 2011; Newstead, 2018); parent expectations that are too high on their children's math performance (Namkung et al., 2019; Olson \& Stoehr, 2019; Tomasetto et al., 2011).

\section{Method}

\section{Procedure}

This research aims to analyze gender and EI towards MA. The independent variables are gender and EI, while the dependent variable is MA. Participants were recruited from senior high schools across East Java, Indonesia, with three categories of regions (low to high) based on the availability of educational infrastructure.

The questionnaire package was administered in the classes by the teacher representing the researcher using Google Form. Completion of the questionnaire package took approximately 5 minutes to answer ten open-ended questions about MA.

\section{Participant}

A total of 450 senior high school students in East Java, Indonesia, participated in this quantitative study. They consisted of 169 male and 281 female students of the tenth and eleventh grades. The participants were selected using a simple random sampling technique because the members of the population were considered homogeneous.

\section{Data Collection Technique}

All participants received a questionnaire package previously validated by experts with a high-reliability coefficient. The questionnaires were filled out independently and returned to the researcher online. A Likert scale was used for scoring with the following criteria: 1: strongly disagree; 2: disagree; 3: undecided; 4: agree; and 5: strongly agree.

\section{Result}

To better understand the research results, the analysis was undergone in two stages, calculating descriptive statistics and frequencies for demographic information for all participants and assessing MA based on gender and EI. Table 1 below provides descriptive statistics for the MA of all participants.

Table 1Descriptive Statistic of MA

\begin{tabular}{llllll}
\hline Educational Infrastructure & Gender & Mean & Std. Dev. & $\mathrm{N}$ & $\%$ \\
\hline Level 1 & Male & 35.34 & 7.241 & 50 & 32.89 \\
\cline { 2 - 6 } & Female & 34.25 & 5.857 & 102 & 67.11 \\
\cline { 2 - 6 } & Total & 34.61 & 6.342 & 152 & 33.77 \\
\hline Level 2 & Male & 28.32 & 5.423 & 77 & 55.39 \\
\hline & Female & 27.89 & 6.476 & 62 & 44.61 \\
\hline Level 3 & Total & 28.13 & 5.897 & 139 & 30.88 \\
\hline & Male & 26.74 & 7.279 & 42 & 26.41 \\
\hline Total & Female & 27.09 & 6.026 & 117 & 73.59 \\
\hline & Total & 27.00 & 6.358 & 159 & 35.33 \\
\hline & Male & 30.01 & 7.346 & 169 & 37.6 \\
\hline & Female & 29.86 & 6.901 & 281 & 62.4 \\
\hline
\end{tabular}


Table 1 shows that there are 169 (37.6\%) male and $281(62.4 \%)$ female participants. At each EI, the participant MA is in order from high to low, namely, level 1 with a mean of 34.61 (33.77\%), level 2 of $28.13(30.88 \%)$, and level 3 of $27.00(35.33 \%)$. For the mean of each gender, men have a higher value of $30.01(37.6 \%)$ than women of $29.86(62.4 \%)$. Although the number of women is more significant than men, the mean MA for the men is higher.

To analyze the relationship between gender and EI on MA, a univariate ANOVA test is required. This test involves prerequisite tests, namely normality test (to ensure that the data is normally distributed) and homogeneity test (to ensure the data comes from a homogeneous variant). The normality test used the Kolmogorov-Smirnov One-Sample Test, while the homogeneity test used the Levene's Test of Equality of Error Variances. Table 2 below describes the normality test results.

Table 2Normality Test

\begin{tabular}{lll}
\hline $\mathrm{N}$ & & 450 \\
\hline Normal Parameters $^{\mathrm{a}, \mathrm{b}}$ & Mean & 29.92 \\
\cline { 2 - 3 } & Std. Deviation & 7.063 \\
\hline Test Statistic & & .035 \\
\hline Asymp. Sig. (2-tailed) & & .200 \\
\hline
\end{tabular}

Based on Table 2, the observed significance level (Sig.) is 0.200 , higher than 0.05 . This result means that the data are normally distributed. Another prerequisite is the homogeneity test to find out whether the analyzed data comes from a homogeneous variant. Table 3 below describes the homogeneity test results.

Table 3Homogeneity Test

\begin{tabular}{llll}
\hline $\mathrm{F}$ & $\mathrm{df1}$ & $\mathrm{df2}$ & Sig. \\
\hline 1.571 & 5 & 444 & .167
\end{tabular}

Table 3 shows that the significance level of observation (Sig.) is 0.167 , higher than the significance level set at 0.05 . This result means that the data has a homogeneous variance. Both tests have been fulfilled as prerequisites for the univariate analysis. Table 4 below describes the results of the univariate test.

Table 4Univariate Test

\begin{tabular}{llllll}
\hline Dependent Variable: & Mathematical Anxiety & & & & \\
\hline Source & Type III Sum of Squares & df & Mean Square & F & Sig. \\
\hline Corrected Model & $5188.688^{\mathrm{a}}$ & 5 & 1.037 .738 & 26.771 & .000 \\
\hline Intercept & 353.503 .603 & 1 & 353.503 .603 & 9.119 .350 & .000 \\
\hline EI & 4.751 .228 & 2 & 2.375 .614 & 61.284 & .000 \\
\hline Gender & 15.166 & 1 & 15.166 & .391 & .532 \\
\hline EI*Gender & 33.895 & 2 & 16.948 & .437 & .646 \\
\hline Error & 17.211 .270 & 444 & 38.764 & & \\
\hline Total & 425.183 .000 & 450 & & & \\
\hline Corrected Total & 22.399 .958 & 449 & & & \\
\hline
\end{tabular}

a. $\mathrm{R}$ Squared $=.232$ (Adjusted R Squared $=.223$ )

Based on the above table, in the EI row, $\mathrm{F}=2.337$ with Sig. $=0.000$. This result means that EI has a different influence on MA. In the gender row, $\mathrm{F}=0.391$ with $\mathrm{Sig} .=0.532$. This result means that gender does not have any different influence on MA. The last row of the univariate test series shows that EI and gender have $\mathrm{F}=0.437$ with Sig. $=0.646$. It means that EI and gender do not interact with MA.

Because EI is proven to have a different influence on MA, an advanced test needs to be undergone to find out the difference of each level on MA. It is done by an advanced LSD test with the results as in Table 5 below.

Table 5LSD TestDependent Variable: Mathematical Anxiety

\begin{tabular}{lllll}
\hline & \multicolumn{2}{l}{$(\mathrm{J})$} & & \\
(I) Educational Infrastructure & Infrastructure & Educational & Std. Error & Sig. \\
\hline Level 1 & Level 2 & $6.48^{*}$ & .731 & .000 \\
\cline { 2 - 6 } & Level 3 & $7.61^{*}$ & .706 & .000 \\
\hline Level 2 & Level 1 & $-6.48^{*}$ & .731 & .000 \\
\hline & Level 3 & 1.13 & .723 & .119 \\
\hline Level 3 & Level 1 & $-7.61^{*}$ & .706 & .000 \\
\cline { 2 - 6 } & Level 2 & -1.13 & .723 & .119 \\
\hline
\end{tabular}


Referring to Table 5 above, there is a very significant difference between level 1 and level 2 on EI, as well as between level 1 and level 3. In contrast, between level 2 and level 3, no difference in EI is found.

\section{Discussion}

In this research, we analyze the relationship between gender and EI towards MA. Gender and EI are the independent variables, while MA is the dependent variable. We find the no different influence of gender on student MA. Both male and female students have the same tendency to feel anxious about mathematics. This finding reinforces previous research that gender differences do not influence student MA (Adal \& Yavuz, 2017; Eskici \& Ilgaz, 2019; Hopkins et al., 2017; Ilomo \& Mlavi, 2016; Küçük et al., 2016; James P. Spillane et al., 2018; Sun et al., 2014). However, this result also contradicts the findings of other studies where gender differences influence student MA (Carey et al., 2019; Delgado \& Kassim, 2019; Devine et al., 2012, 2016; Gresham \& Burleigh, 2019; Namkung et al., 2019).

Based on the univariate test results, it is statistically proven that there is no different influence of gender on MA. It means that the hypothesis is rejected. However, as presented in Table 1, the mean MA score of male student MA (30.01) is higher than that for females (29.86) with a difference of 0.15 .

Men and women cannot be distinguished according to intellectual factors but cognitive areas (Halpern, 2012; Santrock, 2018). Theoretically, male students have better math and science skills than female students (DeZolt \& Hull, 2001; Koch, 2003; Santrock, 2018), but this theory is about math skills, not math anxiety, as the two are interrelated (Carey et al., 2019). The higher the level of student MA is, the lower their mathematical skills will be, and vice versa (Carey et al., 2016, 2019).

The results of this research have several similarities and differences with those of previous research. The difference is possible because other variables are not strictly controlled, such as the age of the participants, the number of classes used, the social status of students, etc. Previous research has proven that class differences influence student MA (Akbayır, 2019; Peker \& Şentürk, 2012; Uysal \& Selış1k, 2016). It is a recommendation for future researchers.

Apart from gender, EI is also part of the independent variable of this research. We found that EI has a very significantly different influence on student MA. It means that the hypothesis is accepted. EI consists of three levels (1,2, and 3). They are distinguished by the availability of educational infrastructure in an area as measured by the number of tertiary institutions in the area. Level 1 is the lowest level of EI availability (no more than 7 universities); level 2 is intermediate (around 7-15 universities); level 3 is the highest (more than 15 universities).

As shown in Table 1, the mean of MA at level 1 is the highest, followed by levels 2 and 3 . This result resembles a reciprocal theory where a high EI level will be followed by a low mean of MA and vice versa. It proves that EI has a very significant influence on student MA.

EI is a set of resources for teaching and education capacity building, including academic content, guides for teaching, and learning opportunities for both teachers and students (Camburn \& Han, 2019; Cohen, 2011). It is stated that EI is an instrument for educational organization and educational scholarship (Skobeltsina \& Kuznetsov, 2019). Also, EI is everything related to the school system, learning tools, school infrastructure, technology strengthening, etc. (Takmazyan et al., 2019).

The results of this research prove that there is a similarity with previous research that the infrastructure of a region and school is pivotal for optimal implementation of education (Datnow et al., 2013; James P. Spillane \& Sherer, 2011) and student learning performance (Hopkins et al., 2014). EI is also a necessity, especially in the current disruptive era where ICT is an absolute requirement to be fulfilled (Gil-Flores et al., 2017; Misevičiene et al., 2012).

The availability of adequate EI determines the creation of professional learning made with the school system to support formal learning and teacher work (Cohen, 2011; Shirrell et al., 2019). Through EI, the structures and resources mobilized by the school system enable teachers to provide, maintain, and enhance learning so that students feel comfortable and avoid tension and anxiety (Cohen, 2011; Hopkins \& Spillane, 2015; Shirrell et al., 2019; James P. Spillane et al., 2018; James P. Spillane \& Sherer, 2011). This is following the findings, as shown in Table 5, where areas with an adequate level of EI (level 3) have a very significantly different influence on student MA compared to areas with inadequate EI level (level 1).

Adequate EI and proper use of teaching and physical facilities can improve performance and outcomes (Gujjar et al., 2010; James P. Spillane et al., 2018). One of the adverse effects, if an area is not equipped with adequate EI, is a failure to attract student interest which affects enrollment ratios and results in a waste of time and resources (Dettmer et al., 2014; Gil-Flores et al., 2017; Gujjar et al., 2010). 
Thus, the first hypothesis is rejected, proving that gender does not have a different influence on student MA. In addition, the second hypothesis is accepted, proving that EI has a very significantly different impact on student MA. However, this research has a limitation, namely that moderating variables, such as age and social status of participants, are not controlled even though they may influence the results. This limitation makes a recommendation and clarification for future research.

\section{Conclusion}

The present research confirms that gender does not have a different influence on student MA, and these findings are consistent with previous research (Adal \& Yavuz, 2017; Eskici \& Ilgaz, 2019; Hopkins et al., 2017; Ilomo \& Mlavi, 2016; Küçük et al., 2016; James P. Spillane et al., 2018; Sun et al., 2014). EI also has a different influence on student MA (Datnow et al., 2013; James P. Spillane \& Sherer, 2011; Hopkins et al., 2014; Gil-Flores et al., 2017; Misevičiene et al., 2012).

The results of this research can be used as a reference for teachers and other researchers concerning gender, EI, and student MA. Regarding gender differences, mathematics teachers should avoid comparing their student gender concerning MA. Teachers must also realize that not all students have a high interest in mathematics, so they must be more sensitive to all their students, especially regarding the availability of EI.

\section{Acknowledgment}

We express our gratitude to BPPDN Kemenristekdikti which has fully funded this research and all those who have contributed to the success of this research.

\section{References}

Adal, A. A., \& Yavuz, İ. (2017). The relationship between mathematics self efficacy and mathematics anxiety levels of middle school students. International Journal of Field Education, 3(1), 20-41.

Adetunji, M. A., \& Aloba, O. (2018). Analysis of the distribution pattern and accessibility of students to secondary educational facilities in Lokoja, Kogi State, Nigeria. Analele Universităţii Din Oradea, Seria Geografie, 28(1), 113-124.

Akbayır, K. (2019). An Investigation About High School Students' Mathematics Anxiety Level According To Gender. Journal of Education and Training Studies, 7(7), 62. https://doi.org/10.11114/jets.v7i7.4201

Alkan, V. (2011). One of the barriers to providing effective mathematics teaching: anxiety and its causes. Pamukkale Universitesi Egitim Fakultesi Dergisi-Pamukkale University Journal of Education, 29(29), 89107.

Aydin, M., \& Keskin, İ. (2017). The investigation of 8th graders mathematical anxiety levels in terms of some variables. Kastamonu Education Journal, 25(5), 1801-1818.

Beilock, S. L., Gunderson, E. A., Ramirez, G., \& Levine, S. C. (2010). Female teachers' math anxiety affects girls' math achievement. Proceedings of the National Academy of Sciences of the United States of America, 107(5), 1860-1863. https://doi.org/10.1073/pnas.0910967107

Camburn, E. M., \& Han, S. W. (2019). Infrastructure for teacher reflection and instructional change: An exploratory study. Journal of Educational Change, 53(9), 1689-1699. https://doi.org/10.1017/CBO9781107415324.004

Carey, E., Devine, A., Hill, F., Dowker, A., McLellan, R., \& Szucs, D. (2019). Understanding Mathematics Anxiety: : Investigating the experiences of UK primary and secondary school students. Centre for Neuroscience in Education. https://doi.org/https://doi.org/10.17863/CAM.37744

Carey, E., Hill, F., Devine, A., \& Szücs, D. (2016). The chicken or the egg? The direction of the relationship between mathematics anxiety and mathematics performance. Frontiers in Psychology, 6(January), 1-6. https://doi.org/10.3389/fpsyg.2015.01987

Carvalho, R. G. G. (2016). Gender differences in academic achievement: The mediating role of personality. Personality and Individual Differences, 94, 54-58. https://doi.org/10.1016/j.paid.2016.01.011

Cohen, D. K. (2011). Teaching and its predicaments. Mass.: Harvard University Press.

Datnow, A., Park, V., \& Kennedy-lewis, B. (2013). Affordances and constraints in the context of teacher collaboration for the purpose of data use. Journal of Educational Administration, 51(3), 341-362. https://doi.org/10.1108/09578231311311500

Delgado, K. D. D., \& Kassim, S. R. (2019). Mathematics Anxiety among Young Filipino Learners: Investigating the Influence of Gender and Socio-Economic Status. Online Submission, 31(3), 575-579.

Dettmer, J., Ettel, D., Glang, A., \& McAvoy, K. (2014). Building statewide infrastructure for effective educational services for students with TBI: Promising practices and recommendations. Journal of Head Trauma Rehabilitation, 29(3), 224-232. https://doi.org/10.1097/HTR.0b013e3182a1cd68

Devine, A., Fawcett, K., Szücs, D., \& Dowker, A. (2012). Gender differences in mathematics anxiety and the relation to mathematics performance while controlling for test anxiety. Behavioral and Brain Functions, 8(33), 1-9. https://doi.org/10.1186/1744-9081-8-33 
Devine, A., Hill, F., Carey, E., Szücs, D., \& Devine, A. (2016). Cognitive and emotional math problems largely dissociate: Prevalence of developmental dyscalculia and mathematics anxiety. Journal of Educational Psychology, 110(3), 431-444. https://www.airipa.it/wp-content/uploads/2019/03/devine_etal2018.pdf

DeZolt, D. M., \& Hull, S. H. (2001). Classroom and school climate. In J. Worrel (Ed.), Encyclopedia of Women and Gender. Academic Press.

Dowker, A., Sarkar, A., \& Looi, C. Y. (2016). Mathematics anxiety: What have we learned in 60 years? Frontiers in Psychology, 7(APR). https://doi.org/10.3389/fpsyg.2016.00508

Dursun, Ş., \& Bindak, R. (2011). Elementary education II. examining mathematics anxiety of students. C. Ü. Journal of Social Sciences, 35(1), 18-21.

Eisenberg, N., Martin, C. L., \& Fabes, R. A. (1996). Gender development and gender effects. In D. C. Berliner \& R. C. Calfee (Eds.), Handbook of Educational Psychology. Macmillan Publishing Company.

Eskici, M., \& Ilgaz, G. (2019). High school students and mathematics in the light of attitude, success and gender. Journal of Social Sciences of Mus Alparslan University, 7(1), 335345.

Gil-Flores, J., Rodríguez-Santero, J., \& Torres-Gordillo, J. J. (2017). Factors that explain the use of ICT in secondary-education classrooms: The role of teacher characteristics and school infrastructure. Computers in Human Behavior, 68, 441-449. https://doi.org/10.1016/j.chb.2016.11.057

Goetz, T., Bieg, M., Lüdtke, O., Pekrun, R., \& Hall, N. C. (2013). Do Girls Really Experience More Anxiety in Mathematics? Psychological Science, 24(10), 2079-2087. https://doi.org/10.1177/0956797613486989

Gresham, G., \& Burleigh, C. (2019). Exploring early childhood preservice teachers' mathematics anxiety and mathematics efficacy beliefs. Teaching https://doi.org/10.1080/10476210.2018.1466875

Gujjar, A. A., Khan, N., Baig, M. N., \& Ramzan, M. (2010). A study to evaluate the availability and utilization of physical and instructional facilities in secondary schools of Bajaur Agency (Pakistan). International Online Journal of Educational Sciences, 2(3), 688-701.

Halpern, D. F. (2012). Sex Differences in Cognitive Abilities (Fourth Ed.). Taylor \& Francis.

Hopkins, M., Ozimek, D., \& Sweet, T. M. (2017). Mathematics coaching and instructional reform: Individual and collective change. Journal of Mathematical Behavior, 46, 215-230. https://doi.org/10.1016/j.jmathb.2016.11.003

Hopkins, M., \& Spillane, J. P. (2015). Conceptualizing relations between instructional guidance infrastructure (IGI) and teachers' beliefs about mathematics instruction: Regulative, normative, and cultural-cognitive considerations. Journal of Educational Change, 16(4), 421-450. https://doi.org/10.1007/s10833-015-9257-1

Hopkins, M., Spillane, J. P., Jakopovic, P., \& Heaton, R. M. (2014). Infrastructure redesign and instructional reform in mathematics: Formal structure and teacher leadership. Elementary School Journal, 114(2), 200224. https://doi.org/10.1086/671935

Ilomo, O., \& Mlavi, B. (2016). The availability of teaching and learning facilities and their effects on academic performance in ward secondary schools in Muheza - Tanzania. International Journal of Educational Research, 4(6), 571-582. www.ijern.com

Koch, J. (2003). Gender issue in the classroom. In I. B. Weiner (Ed.), Handbook of Psychology (7th ed., pp. 259-281). John Wiley \& Sons, Inc.

Küçük, D. B., Cansız, Ş., Deniz, D., Çevik K. C., \& İşleyen, T. (2016). The investigation of primary school teacher candidates' anxiety levels for teaching mathematics in terms of different variables (the example of Bayburt). Bayburt University Journal of Education, 11(2), 379-390.

Lindsey, L. L. (2016). Gender Roles-A Sociological Perspective (Sixth Ed.). Taylor \& Francis.

Ma, L. (2010). Knowing and teaching elementary mathematics. Routledge.

Maloney, E. A., Ansari, D., \& Fugelsang, J. A. (2011). The effect of mathematics anxiety on the processing of numerical magnitude. Quarterly Journal of Experimental Psychology, 64(1), 10-16. https://doi.org/10.1080/17470218.2010.533278

Misevičiene, R., Ambraziene, D., Tuminauskas, R., \& Pažereckas, N. (2012). Educational infrastructure using virtualization technologies: Experience at Kaunas university of technology. Informatics in Education, 11(2), 227-240.

Namkung, J. M., Peng, P., \& Lin, X. (2019). The Relation Between Mathematics Anxiety and Mathematics Performance Among School-Aged Students: A Meta-Analysis. In Review of Educational Research (Vol. 89, Issue 3). https://doi.org/10.3102/0034654319843494

Newstead, K. (2018). Aspects of Childrens Mathematics Anxiety Author: Karen Newstead Source : Educational Studies in Mathematics. Educational Studies in Mathematics, 36(1), 53-71.

Olson, A. M., \& Stoehr, K. J. (2019). From numbers to narratives: Preservice teachers experiences' with mathematics anxiety and mathematics teaching anxiety. School Science and Mathematics, 119(2), $72-82$. https://doi.org/10.1111/ssm.12320

Peker, M., \& Şentürk, B. (2012). An investigation of 5th grade students' mathematics anxiety in terms of some variables. Journal of Social Sciences of Dumlupınar University, 34, 21-32. 
Richardson, F. C., \& Suinn, R. M. (1972). The Mathematics Anxiety Rating Scale: Psychometric data. Journal of Counseling Psychology, 19(6), 551-554. https://doi.org/10.1037/h0033456

Santrock, J. W. (2018). Educational psychology (6th ed.). McGraw-Hill Education.

Schunk, D. H., \& DiBenedetto, M. K. (2020). Motivation and social cognitive theory. Contemporary Educational Psychology, 60(December 2019), 101832. https://doi.org/10.1016/j.cedpsych.2019.101832

Shirrell, M., Hopkins, M., \& Spillane, J. P. (2019). Educational infrastructure, professional learning, and changes in teachers' instructional practices and beliefs. Professional Development in Education, 45(4), 599-613. https://doi.org/10.1080/19415257.2018.1452784

Skobeltsina, K., \& Kuznetsov, A. (2019). Research on Public Satisfaction with Educational Infrastructure of Advanced Development Territories. International Conference on the Development of Education in Eurasia (ICDEE 2019), 316(Icdee), 36-41. https://doi.org/10.2991/icdee-19.2019.7

Slavin, R. E. (2006). Educational Psychology (8th ed.). Pearson Education, Inc.

Spillane, J. P., Shirrell, M., \& Hopkins, M. (2016). Designing and deploying a professional learning community (PLC) organizational routine: Bureaucratic and collegial arrangements in tandem. Les Dossiers Des Sciences de l'éducation, 35, 97-122.

Spillane, James P., \& Sherer, J. Z. (2011). Organizational Routines as Coupling Mechanisms: Policy, School Administration, and the Technical Core. American Educational Research Journal, 48(3), 586-619. https://doi.org/10.3102/0002831210385102

Spillane, James P., Shirrell, M., \& Adhikari, S. (2018). Constructing "Experts" Among Peers: Educational Infrastructure, Test Data, and Teachers' Interactions About Teaching. Educational Evaluation and Policy Analysis, 40(4), 586-612. https://doi.org/10.3102/0162373718785764

Stigler, J. W., \& Hiebert, J. (1999). The teaching gap. NY: The Free Press.

Sun, M., Wilhelm, A. G., Larson, C. J., \& Frank, K. A. (2014). Exploring colleagues' professional influence on mathematics teachers' learning. Teachers College Record, 116(6), 1-30.

Takmazyan, A. S., Rukina, S. N., Samoylova, K. N., \& Gerasimova, K. A. (2019). Public private partnership as a tool for the development of educational infrastructure. International Journal of Economics and Business Administration, 7(1), 535-544. https://doi.org/10.35808/ijeba/299

Tomasetto, C., Alparone, F. R., \& Cadinu, M. (2011). Girls' Math Performance Under Stereotype Threat: The Moderating Role of Mothers' Gender Stereotypes. Developmental Psychology, 47(4), 943-949. https://doi.org/10.1037/a0024047

Uysal, F., \& Selışık, A. (2016). An investigation about high school students' mathematics anxiety level according to some variables. Journal of Theoretical Educational Science, 9(1), 146-164.

Vukovic, R. K., Kieffer, M. J., Bailey, S. P., \& Harari, R. R. (2013). Mathematics anxiety in young children: Concurrent and longitudinal associations with mathematical performance. Contemporary Educational Psychology, 38(1), 1-10. https://doi.org/10.1016/j.cedpsych.2012.09.001

Wang, Z., Rimfeld, K., Shakeshaft, N., Schofield, K., \& Malanchini, M. (2020). The longitudinal role of mathematics anxiety in mathematics development: Issues of gender differences and domain-specificity. Journal of Adolescence, 80(March), 220-232. https://doi.org/10.1016/j.adolescence.2020.03.003

Zakaria, E., Zain, N. M., Ahmad, N. A., \& Erlina, A. (2012). Mathematics anxiety and achievement among secondary school students. American Journal of Applied Sciences, 9(11), 1828-1832. https://doi.org/10.3844/ajassp.2012.1828.1832 